\title{
PEMAHAMAN SISWA SMP DALAM MEMECAHKAN MASALAH ALJABAR DITINJAU DARI KECERDASAN SPASIAL SEDANG
}

\section{UNDERSTANDING OF SMP STUDENTS IN SOLVING ALGEBRA PROBLEMS FROM MODERATE SPATIAL INTELLIGENCE}

\author{
Setia Widia Rahayu ${ }^{1)}$ \\ 1 Jurusan Matematika, Fakultas Keguruan dan Ilmu Pendidikan, Universitas Borneo Tarakan \\ Jalan Amal Lama Nomor 1, Tarakan \\ Email: ${ }^{1}$ setia.widiaayu@yahoo.com
}

\begin{abstract}
ABSTRAK
Penelitian ini merupakan penelitian deskriptif dengan pendekatan kualitatif yang bertujuan untuk mendeskripsikan pemahaman siswa SMP dalam memecahkan masalah aljabar ditinjau dari kecerdasan spasial. Subjek penelitian ini terdiri 1 siswa kelas VIII. Penelitian ini dimulai dengan menentukan subjek dengan menggunakan instrumen tes kecerdasan majemuk, kemudian dilanjutkan dengan pemberian TPM dan wawancara. Pengecekan keabsahan data menggunakan triangulasi waktu.Hasil penelitian menunjukkan bahwa subjek yang memiliki tingkat kecerdasan sedang Subjek dalam membaca dan menggali masalah memiliki jenis pemahaman formal. Di tahap ini subjek terlebih dahulu membaca secara teliti permasalahan yang diberikan, kemudian menuliskan yang diketahui dan ditanyakan, menyatakan kembali apa yang diketahui dan ditanyakan, selain itu subjek menggunakan bahasa simbol dan menyatakan informasi yang diperoleh dengan disertai penalaran logis yang menghubungkan konsep-konsep ke dalam bentuk aljabar. Sedangkan di tahap membuat rencana, subjek memiliki jenis pemahaman relasional. Subjek ketika di tahap ini menyebutkan rencana pemecahan yang akan digunakan, selain itu subjek memiliki pengalaman menyelesaikan masalah yang mirip dengan masalah yang diberikan dan berhasil memecahkan masalah tersebut. Selanjutnya subjek mampu menyebutkan metode yang akan digunakan untuk memecahkan permasalahan yang diberikan berdasarkan cara yang pernah diterapkan dan berhasil digunakan. Pada tahap melaksanakan rencana pemecahan masalah, subjek memiliki jenis pemahaman relasional. Di tahap ini subjek melaksanakan rencana yang telah dirancang untuk memecahkan masalah dan subjek mampu menjelaskan langkah-langkah penyelesaian yang digunakan, tetapi subjek tidak memaknai simbol/notasi yang digunakan dalam pemecahan masalah. Untuk tahap melihat kembali dan merefleksi, subjek memiliki jenis pemahaman relasional, karena subjek memeriksa jawaban yang diperoleh dengan memperhatikan langkah-langkah yang diterapkan apakah sudah sesuai rencana.
\end{abstract}

\section{Kata Kunci : Kecerdasan Spasial; Pemecahan Masalah Aljabar; Pemahaman}

\begin{abstract}
This study is a descriptive study with a qualitative approach that aims to describe the junior high students' understanding in algebraic problem solving based on spatial intelligence. The Subject of the research is one students of eighth grade students of SMP. The choice of the subject was determined by 1) multiple intelligences test instruments; 2) algebraic problem solving test; 3 ) interviews. Time triangulation was used to improve the quality of the data

The results of study shows that subject has a middle of spatial intelligence, when reading and explore the subject matter has a formal understanding. subject first read the problem, then write a note and asked, subjects using language symbols to reveal information obtained with logical reasoning that links concepts in algebraic form. In stage plan, the subject has a kind of relational understanding. Mention the subject at this stage of the plan
\end{abstract}


solution that will be used, and the subjects had experience solving problems similar to the given problem and managed to solve the problem. Furthermore, the subject was able to mention the method that will be used to solve a given problem based on the way that once applied and successfully used. in the problem-solving phase of implementing the plan, the subject has kind of relational understanding. Subject to implement a plan which has been designed to solve the problem and the subject is able to explain the steps used settlement, but the subject was not interpret the symbols used to solve the problem. To look back and reflect, the subject has a kind of relational understanding, because the subject check answers obtained by taking into account measures adopted what has been according to plan.

\section{Keywords: Spatial Intelligence; Algebraic Problem Solving; Understanding}

\section{PENDAHULUAN}

Perkembangan matematika tidak tergantung pada ilmu-ilmu lain. Banyak cabang matematika yang dulu biasa disebut dengan matematika murni, dikembangkan oleh beberapa matematikawan yang mencintai dan belajar matematika hanya sebagai hobi tanpa memperdulikan fungsi dan manfaatnya untuk ilmu-ilmu lain. Cabang dari matematika yang memiliki peran sangat penting salah satunya adalah aljabar. French (2002) mengatakan bahwa, aljabar adalah penghubung ke geometri, karena geometri berkaitan erat dengan variabel, sudut, panjang, luas dan volumejuga memberikan kontribusi dalam aljabar pada bidang persegi dan kubus.

Metode aljabar dikatakan sebagai alat yang ampuh untuk memecahkan permasalahan geometri dan untuk menyajikan pembuktian geometri.Peranan aljabar yang fundamental dalam pendidikan matematika, telah menjadikan aljabar sebagai salah satu bidang dalam matematika yang menjadi fokus para guru dan pakar pendidikan. Berdasarkan hasil penelitian MacGregor (2012) ditemukan bahwa siswa yang berusia sampai dengan 15 tahun , belum mampu menginterpretasikan huruf-huruf aljabar sebagai suatu generalisasi angka bahkan suatu huruf yang belum diketahui nilainya.

Dari hasil observasi peneliti di salah satu sekolah SMP diperoleh fakta bahwa, siswa kelas VIII lebih dari $40 \%$ masih belum memahami langkah langkah dalam memecahkan masalah matematika, khususnya bidang aljabar. Kondisi ini yang membuat peneliti ingin mengadakan penelitan dengan judul "Pemahaman Relasional Siswa SMP Dalam Memecahkan Masalah Aljabar Ditinjau Dari Kecerdasan Spasial".

Dalam hal ini pemahaman dapat diartikan sebagai proses pembelajaran yang diikuti hasil belajar sesuai dengan tujuan tujuan pembelajaran. Arikunto(2009) menyatakan bahwa pemahaman (comprehension) adalah bagaimana seorang mempertahankan, membedakan, menduga (estimates), menerangkan, memperluas, menyimpulkan, menggeneralisasikan, memberikan contoh, menuliskan kembali, dan memperkirakan. Sedangkan dalam buku psikologi pendidikan matematika, Skemp (1987) mendefinisikan pemahaman ke dalam tiga kategori yaitu, pemahaman instrumental, pemahaman relasional, dan pemahaman formal.

Pemahaman instrumental adalah kemampuan untuk menerapkan aturan yang diingat sesuai dengan solusi dari masalah tanpa mengetahui mengapa aturan tersebut berlaku. Pemahaman relasional adalah kemampuan untuk menyimpulkan aturan spesifik atau prosedur yang lebih dari hubungan matematis umum. Pemahaman formal adalah kemampuan untuk 
menghubungkan simbol matematika dan notasi dengan ide-ide matematika yang relevan dan untuk menggabungkan ideide ke dalam penalaran logis. Dalam penelitian pemahaman siswa dalam memecahkan masalah aljabar akan mengadopsi dari pemahaman yang dikemukakan oleh Skemp.

Masalah matematika pada umumnya berbentuk soal matematika, namun tidak semua soal matematika merupakan masalah. Soal matematika dapat dikatakan suatu masalah apabila siswa belum pernah menyelesaikan soal semacam itu, dan untuk menjawab soal tersebut membutuhkan analisis untuk menemukan pola dan formula tertentu.

Peneliti mendefinisikan masalah dalam penelitian ini, adalah suatu soal yang harus dipecahkan oleh seseorang (termasuk siswa), namun penyelesaiannya tidak dapat dilakukan secara rutin dan tidak langsung ditemukan penyelesaiannya. Masalah matematika dalam matematika sekolah disajikan secara khas dalam bentuk verbal, gambar, atau simbol matematika atau kombinasi dari ketiganya. Adapun indikator pemahaman yang akan digunakan dalam peneliian ini terinci dalam tabel berikut :

Tabel 1. Indikator Pemahaman Siswa dalam Pemecahan Masalah Aljabar

\begin{tabular}{|c|c|c|c|}
\hline No & $\begin{array}{l}\text { Fase Pemecahan } \\
\text { Masalah }\end{array}$ & $\begin{array}{c}\text { Jenis } \\
\text { Pemahaman }\end{array}$ & Indikator \\
\hline \multirow[t]{3}{*}{1} & $\begin{array}{l}\text { Membaca dan } \\
\text { menggali }\end{array}$ & Instrumental & $\begin{array}{l}\text { - Mengungkapkan apa yang diketahui dan yang } \\
\text { ditanyakan dalam soal tanpa menghubungkan } \\
\text { konsep dan tanpa menggunakan representasi } \\
\text { simbol atau notasi. }\end{array}$ \\
\hline & & Relasional & $\begin{array}{l}\text { - Mengungkapkan apa yang diketahui dan } \\
\text { ditanyakan dengan benar. } \\
\text { - Menghubungkan konsep-konsep yang ada pada } \\
\text { masalah yang diberikan. }\end{array}$ \\
\hline & & Formal & $\begin{array}{l}\text { - Mengungkapkan apa yang diketahui dan } \\
\text { ditanyakan dengan benar. } \\
\text { - Menghubungkan konsep-konsep yang ada pada } \\
\text { masalah yang diberikan. } \\
\text { - Mempresentasikannya dengan simbol atau } \\
\text { notasi yang sesuai. }\end{array}$ \\
\hline \multirow[t]{3}{*}{2} & $\begin{array}{l}\text { Membuat rencana } \\
\text { untuk memecahkan } \\
\text { masalah }\end{array}$ & Instrumental & $\begin{array}{l}\text { - Menyusun rencana dengan mengingat masalah } \\
\text { sebelumnya yang telah berhasil dipecahkan dan } \\
\text { mirip dengan masalah yang diberikan. }\end{array}$ \\
\hline & & Relasional & $\begin{array}{l}\text { - Menyusun rencana dengan mengingat masalah } \\
\text { lain yang telah berhasil dipecahkan dan mirip } \\
\text { dengan masalah yang diberikan. } \\
\text { - Menghubungkan konsep-konsep yang ada pada } \\
\text { masalah yang diberikan dengan konsep yang } \\
\text { ada pada masalah yang mirip dan telah berhasil } \\
\text { dipecahkan sebelumnya. }\end{array}$ \\
\hline & & Formal & $\begin{array}{l}\text { - Menyusun rencana dengan } \\
\text { memperhatikan/mengingat masalah lain yang } \\
\text { telah berhasil dipecahkan dan mirip dengan } \\
\text { masalah yang diberikan. } \\
\text { - Menghubungkan konsep-konsep yang ada pada } \\
\text { masalah yang diberikan dengan konsep yang } \\
\text { ada pada masalah yang mirip dan telah berhasil } \\
\text { dipecahkan sebelumnya. } \\
\text { - Menggunakan simbol/notasi atau ide-ide } \\
\text { matematika yang relevan serta penalaran yang } \\
\text { logis. }\end{array}$ \\
\hline 3 & $\begin{array}{l}\text { Melaksanakan } \\
\text { rencana untuk }\end{array}$ & Instrumental & $\begin{array}{l}\text { - Melaksanakan rencana yang telah dibuat pada } \\
\text { fase- } 2 \text {. }\end{array}$ \\
\hline
\end{tabular}




\begin{tabular}{|c|c|c|c|}
\hline & memecahkan masalah & & \\
\hline & & Relasional & $\begin{array}{l}\text { - Melaksanakan rencana yang telah dibuat pada } \\
\text { fase-2. } \\
\text { - Menjelaskan alasan mengapa langkah-langkah } \\
\text { penyelesaian dapat diterapkan. }\end{array}$ \\
\hline & & Formal & $\begin{array}{l}\text { - Melaksanakan rencana yang telah dibuat pada } \\
\text { fase-2. } \\
\text { - Menjelaskan alasan mengapa langkah-langkah } \\
\text { penyelesaian dapat diterapkan. } \\
\text { - Memaknai simbol atau notasi yang digunakan } \\
\text { dengan menggunakan penalaran yang logis. }\end{array}$ \\
\hline 4 & $\begin{array}{l}\text { Melihat kembali dan } \\
\text { merefleksi }\end{array}$ & Instrumental & $\begin{array}{l}\text { - Memeriksa jawaban yang diperoleh dengan } \\
\text { memperhatikan apakah langkah yang } \\
\text { diterapkan sudah sesuai dengan prosedur yang } \\
\text { direncanakan pada fase- } 2 \text {. }\end{array}$ \\
\hline & & Relasional & $\begin{array}{l}\text { - Memeriksa jawaban yang diperoleh dengan } \\
\text { memperhatikan apakah langkah yang } \\
\text { diterapkan sudah sesuai dengan prosedur yang } \\
\text { direncanakan pada fase-2. } \\
\text { - Memeriksa apakah jawaban yang diperoleh } \\
\text { telah menjawab permasalahan yang diberikan. }\end{array}$ \\
\hline & & Formal & $\begin{array}{l}\text { - Memeriksa jawaban yang diperoleh dengan } \\
\text { memperhatikan apakah langkah yang } \\
\text { diterapkan sudah sesuai dengan prosedur yang } \\
\text { direncanakan pada fase-2 } \\
\text { - Memeriksa apakah jawaban yang diperoleh } \\
\text { telah menjawab permasalahan yang diberikan. } \\
\text { - Memeriksa apakah simbol atau notasi atau ide- } \\
\text { ide matematika yang digunakan telah } \\
\text { diterapkan dengan benar dan menggunakan } \\
\text { penalaran yang logis. }\end{array}$ \\
\hline
\end{tabular}

Sumber. Diadaptasi dari Krulik, Rudrick \& Milou (2003) dan Skemp (1987)

Kecerdasan spasial adalah salah satu dari kecerdasan majemuk (multiplle Intelligence) yang pertama kali dikemukakan oleh Gardner (1983) dalam bukunya Frames of Mind. Gardner menyatakan bahwa kecerdasan spasial adalah kemampuan untuk membentuk suatu gambaran mental tentang tata ruang atau menghadirkan dunia mengenai ruang secara internal di dalam pikirannya (mind). Kecerdasan spasial yang dimaksud dalam penelitian ini adalah kemampuan berimajinasi memvisualisasikan suatu objek ke dalam ruang dua dimensi atau tiga dimensi termasuk kemampuan memahami informasi yang disajikan dalam bentuk representasi spasial berupa diagram, gambar, grafik dan simbol-simbol serta menggunakannya dalam penalaran.

\section{METODE PENELITIAN}

Jenis penelitian ini adalah deskriptif dengan pendekatan kualitatif. Penelitian deskriptif diarahkan untuk mendeskripsikan gejala-gejala, faktafakta atau kejadian-kejadian secara sistematis dan akurat mengenai sifat-sifat subjek penelitian, selain itu juga untuk memahami fenomena tentang apa yang dialami oleh subjek penelitian misalnya perilaku, persepsi, tindakan, dan lain-lain, secara holistik, dan dengan cara deskripsi dalam bentuk kata-kata dan bahasa dengan memanfaatkan berbagai metode ilmiah.

Subjek penelitian adalah siswa kelas VIII SMPN 3 Tarakan. Peneliti akan memilih subjek dari hasil Tes Kecerdasan Spasial (TKS), dan subjek yang dipilih harus memiliki kemampuan berkomunikasi yang baik, dan komunikatif. Dengan demikian peneliti akan berdiskusi dengan guru karena guru 
lebih mengetahui karakteristik siswa sehari-hari.

Pengumpulan data dalam penelitian ini dilakukan dengan dua teknik yaitu menggunakan tes tertulis dan wawancara. Proses pengumpulan data tes tertulis dan diperoleh hasil tes tertulis. Selanjutnya peneliti melakukan wawancara kepada subjek penelitian. Dalam pengumpulan data, peneliti memberikan tes pertama tertulis kepada subjek peneliti. Setelah memberikan tes, peneliti melakukan wawancara terhadap permasalahan yang telah dikerjakan.

Dalam penelitian ini teknik analisa data dilakukan melalui tahap-tahap berikut:

1. Penelaahan

Data hasil transkip dan pekerjaan siswa kemudian ditelaah secara mendalam untuk data yang akan disajikan dalam bentuk narasi.

2. Mereduksi data

Data yang telah ditelaah kemudian direduksi. Reduksi data ini dimaksudkan untuk menyeleksi dan memfokuskan data-data yang telah diperoleh dilapangan.

3. Triangulasi

Untuk menjamin keabsahan data dalam penelitian ini, diperlukan teknik pengujian keabsahan data. Teknik pengujian keabsahan data ini dilakukan triangulasi.

4. Penarikan Simpulan

Penarikan simpulan yaitu kegiatan merangkum data serta memeriksa kebenaran data.

\section{HASIL DAN PEMBAHASAN}

Pemilihan subjek penelitian dilakukan berdasarkan langkah-langkah yang telah ditentukan pada Bab III. Tes Identifikasi Kecerdasan Spasial (TIKS) disebarkan pada satu kelas penelitian. Berdasarkan hasil tes dan konsultasi peneliti dengan guru kelas diperoleh 1 subjek penelitian ditinjau dari kecerdasan spasial sedang. Berdasarkan dari data tes tertulis dan wawancara diatas, terungkap bahwa subjek terpilih dalam membaca dan menggali masalahdengan menuliskan diketahui:

a) Menuliskan apa yang diketahui dalam bahasa simbol.

b) Menuliskan apa yang ditanyakan dalam bahasa verbal.

c) Menggunakan dua variabel untuk menyatakan banyak objek yang berbeda.

d) Menyatakan hubungan dua variabel ke dalam sistem persamaan linier.

Sedangkan pada tahap membuat rencana subjek yang dilakukan subjek adalah:
a) Memiliki pengalaman menyelesaikan permasalahan yang mirip dengan masalah yang diberikan.

b) Menghubungkan pengalaman menyelesaikan permasalahan sebelumnya dengan masalah yang diberikan saat ini.

c) Mengidentifikasi metode yang akan digunakan untuk memecahkan masalah yang diberikan.

d) Merencanakan untuk menggunakan cara eliminasi dan subtitusi

e) Menetapkan rencana yang sama dengan strategi yang pernah digunakan pada pengalaman sebelumnya, untuk memecahkan masalah yang diberikan.

Pada tahap melaksanakan rencana penyelesaian masalah aljabar, yang dilakukan subjek adalah :

a) Menyelesaikan persamaan linier dua variabel sesuai aturan eliminasi dan subtitusi yang berlaku

b) Melaksanakan pemecahan masalah, menggunakan metode eliminasi dan subtitusi sesuai rencana. 
c) Menyederhanakan bentuk persamaan untuk mendapatkan nilai dari setiap variabel.

d) Mengerjakan langkah-langkah penyelesaian sesuai metode eliminasi dan subtitusi yang berlaku.

e) Menafsirkan solusi pemecahan masalah ke dalam bahasa soal mula-mula.

Dalam tahap melihat kembali dan merefleksi subjek melakukan:

a) Memeriksa apakah langkahlangkah metode eliminasi dan subtitusi yang digunakan sudah sesuai dengan prosedur yang direncanakan.

b) Memeriksa jawaban apakah sudah menjawab permasalahan yang diberikan.

c) Memutuskan jawaban yang diperoleh sudah benar.

Subjek dengan kecerdasan spasial sedang hanya memenuhi dua dari tiga pemahaman yang dikemukakan oleh Skemp (1987). Subjek berkecerdasan spasial sedang memiliki jenis pemahaman formal ketika membaca dan menggali masalah.

\section{KESIMPULAN}

Berdasarkan hasil analisis data penelitian dan pembahasan yang telah diuraikan pada bab sebelumnya, maka dapat ditarik kesimpulan sebagai berikut. Subjek dengan kecerdasan spasial sedang, memiliki jenis pemahaman formal pada tahap membaca dan menggali masalah, karena subjek mengungkapkan apa yang diketahui dan ditanyakan dengan benar, menghubungkan konsepkonsep yang ada pada masalah yang diberikan, dan mempresentasikan yang diketahui dengan menggunakan simbol/notasi yang sesuai. Ketika dalam tahap membuat rencana subjek kecerdasan spasial sedang memiliki jenis pemahaman relasional, yaitu subjek menyusun rencana dengan mengingat masalah sebelumnya yang berhasil dipecahkan dan mirip dengan masalah yang diberikan, dan subjek mampu menghubungkan konsep-konsep yang ada pada masalah yang diberikan dengan konsep-konsep pada masalah sebelumnya dan telah berhasil dipecahkan. Selanjutnya pada tahap melaksanakan rencana subjek kecerdasan spasial tinggi memiliki pemahaman relasional, karena subjek melaksanakan rencana yang telah dibuat, dapat menjelaskan alasan mengapa langkah-langkah penyelesaian diterapkan, tetapi tidak mampu memaknai simbol/notasi yang digunakan. Dalam tahap melihat kembali dan merefleksi subjek kecerdasan spasial sedang memiliki pemahaman relasional, karena subjek memeriksa jawaban apakah sudah sesuai dengan langkahlangkah yang direncanakan, dan subjek memeriksa apakah jawaban sudah menjawab permasalahan yang diberikan, akan tetapi subjek tidak memeriksa kembali apakah simbol-simbol yang digunakan sudah benar.

\section{DAFTAR PUSTAKA}

Arikunto, Suharsimi. 2009. Dasar-dasar Evaluasi Pendidikan. Aneka Cipta: Jakarta.

French, Doug.2002. Teaching and Learning Algebra. Great Britain : Bookcraft.Ltd.

Krulik, S., Rudnick, J., Milou, E. 2003. Teaching Mathematics in Middle School A Practical Guide. Printed in The United States of America.

MacGregor, M., \& Stacey, K. 1997. Students' understanding of Algebraic notation: 11-15. Educational Studies in Mathematics , 33(1), 1-19. Retrieved on January 15,2008 from http://www.edfac.unimelb.edu.au/DS ME/staff/. Diakses 2 November 2013.

Skemp, Richard. 1987. The Psychology of Learning Mathematics.Great Britain: Hazell Watson \& Viney. 
